\title{
PENGARUH BUDAYA ORGANISASI DAN KERJA STRES TERHADAP KEPUASAN KERJA GURU SMA KATOLIK SE- JAKARTA TIMUR
}

\author{
Lamria Novalita', Matin, ${ }^{2}$ Nurjannah $^{3}$ \\ Email: novalita.siahaan@yahoo.co.id
}

\begin{abstract}
Abstrak: Penelitian ini bertujuan untuk melihat adanya pengaruh dari (I) budaya organisasi, (2) stres kerja, (3) kepuasan kerja para Guru SMA Sekolah Swasta Katolik Se Jakarta Timur. Penelitian ini menggunakan metode survey dengan pendekatan kuantitatif. yang menjelaskan hubungan atau korelasional kausal yang biasa disebut analisis jalur. Survey dilakukan sejak Maret 2018 sampai Mei 2018 dengan melibatkan 103 orang Guru SMA. Sampel dalam penelitian ini ditentukan secara acak dengan menggunakan rumus Slovin dengan uji coba instrument sebanyak 24 Guru. Temuan dari hasil penelitan ini mengindikasikan: pertama, adanya pengaruh budaya organisasi langsung positif dan signifikan terhadap kepuasan kerja para Guru. Kedua, adanya pengaruh stres kerja secara langsung negatif terhadap kepuasan kerja. Ketiga, adanya pengaruh budaya organisasi secara langsung negatif terhadap stres kerja. Berdasarkan hasil penelitian ini, disarankan kepada kepala sekolah sebagai agar dapat menjadi teladan bagi Guru-Guru didalam menjalankan nilai-nilai yang terkandung dalam budaya organisasi. yayasan membantu pimpinan sekolah dalam hal kebijakan pengupahan, penghargaan dan promosi jabatan yang layak bagi para Guru. Guru menjalankan nilai-nilai budaya organisasi yang ada, menghormati pimpinan sekolah dan sesama rekan kerja, sehingga tercipta suasana yang harmonis dan saling dukung sehingga tingkat kepuasan kerja dapat terpenuhi.
\end{abstract}

Kata kunci: Budaya Organisasi, Stres Kerja, Kepuasan Kerja

\section{PENDAHULUAN}

Pendidikan merupakan sektor terpenting yang diperhatikan Pemerintah Indonesia dalam meningkatan dan memajukan taraf hidup suatu bangsa. Sistem Pendidikan Nasional (Sisdiknas) dalam Undang-Undang No. 20 tahun 2003 menyebutkan Pendidikan Nasional berfungsi mengembangkan kemampuan dan membentuk watak serta peradaban bangsa yang bermartabat dalam rangka mencerdaskan kehidupan bangsa. Gereja Katolik dengan visi yakni mewujudkan masyarakat Katolik yang kualitas iman dan takwanya tinggi mengajak masyarakat beragama Katolik untuk berperan serta secara aktif dalam mencapai tujuan pembangunan bangsa.

Saat ini sekolah-sekolah SMA di DKI Jakarta khususnya Jakarta Timur terus mengalami perkembangan. Perkembangan menimbulkan persaingan yang sehat antar sekolah SMA khususnya SMA Swasta, akan tetapi bila melihat data jumlah murid dari beberapa SMA Katolik yang diobservasi justru mengalami penurunan. Salah satu indikasi dari menurunnya minat siswa disebabkan oleh menurunnya tingkat rata-rata nilai Ujian Nasional sekolah tersebut. Seluruh komponen SMA Katolik tentu berjuang bersama dalam menghadapi fenomena tersebut.

Salah satu kunci keberhasilan untuk meningkatkan kualitas pendidikan adalah keberadaan Guru yang profesional. Adapun ciri-ciri Guru yang profesional adalah (I) memiliki bakat, minat, panggilan jiwa, dan idealism, (2) memiliki komitmen untuk meningkatkan mutu pendidikan, keimanan, ketakwaan, dan akhlak mulia, (3) memiliki kualifikasi akademik dan latar belakang pendidikan sesuai dengan bidang tugas. Keberadaan Guru yang professional sendiri dipengaruhi oleh tingkat kepuasan kerja para Guru, dimana “...job dissatisfaction caused

${ }^{1}$ Graduate Student of Education Management State University of Jakarta, Indonesia

${ }^{2}$ First Advisor, Graduate of Management Education-State University of Jakarta, Indonesia

${ }^{3}$ Second Advisor, Graduate of Management Education-State University of Jakarta, Indonesia 
disengagement of some teachers with a consequent lack of focus on professional activities and being negative in their job", Ketidakpuasan dapat membuat para Guru tidak fokus pada pekerjaannya dan ini berpegaruh terhadap sikap profesionalisme Guru.

untuk mencapai kesamaan tujuan antara sekolah dan Guru dalam meningkatkan kualitas sekolah, maka sekolah perlu meningkatkan kepuasan kerja para Guru sehingga "...as the Job Sastifaction levels of teachers go up so do their Organinaztion Comitment levels". Guru yang memiliki tingkat kepuasan tinggi termotivasi untuk mewujudkan tujuan sekolah. Kepuasan kerja akan tercapai bila Guru merasa nyaman dan senang bekerja. Sikap merasa nyaman dan senang akan terbangun didalam Budaya organisasi yang kuat dimana budaya organisasi yang kuat akan membuat seseorang nyaman serta semangat dalam melaksanakan tugasnya dengan baik. Namun, jika budaya organisasi tidak sesuai maka berdampak pada rendahnya kepuasan kerja Guru.

Seorang Guru senang dalam bekerja dan mencapai kepuasan kerja jika merasa puas dengan hasil pekerjaannya. Hasil kerja yang bermutu hanya bisa dicapai jika akan adanya penghargaan atas hasil yang dicapai, kebijakan promosi, pengawasan atasan, hubungan dengan rekan kerja dan kondisi tempat kerja yang baik dan tidak menimbulkan tekanan kerja. Bila Guru mendapatkan tekanan kerja dan pihak sekolah baik pimpinan atau rekan kerja tidak menanggapinya dengan positif akan memberikan stres kerja bagi Guru. Dan ini tentunya berpengaruh terhadap tingkat kepuasan para Guru.

Berdasarkan latar belakang dan identifikasi masalah yang telah digambarkan terlihat bahwa kepuasan kerja Guru berkaitan dengan budaya organisasi dan stres kerja. Oleh karena itu, penelitian ini dibagi menjadi dua variabel. Pertama, variabel bebas yaitu budaya organisasi dan stress kerja, dan variabel terikat yaitu kepuasan kerja Guru.

\section{Kepuasan Kerja}

Defenisi kepuasan kerja menurut Stephen Robbin,

Job satisfaction can be defined as a positive feeling about one's job resulting from evaluation of its characteristics. A person with a high level of job satisfaction holds positive feeling about the job, while a person who is dissatisfied holds negative feelings about the job.

Kepuasan kerja didefinisikan sebagai perasaan positif karyawan terhadap hasil pekerjaannya dari hasil penilaian berdasarkan mutu pekerjaan itu sendiri. Robbin, menyatakan bahwa seorang karyawan dengan kepuasan kerja yang tinggi memiliki perasaan yang positif terhadap pekerjaan, sementara itu karyawan dengan kepuasan kerja yang rendah memiliki perasaan kurang baik terhadap pekerjaanya.

Pendapat Angelo Kinicki, Brian K. Williams mengatakan bahwa kepuasan kerja adalah: Job satisfaction is the extent to which you feel positive or negative about various aspects of your work. Their overall satisfaction depends on how they feel about several components, such as work, pay, promotions, coworkers and supervision.

Berdasarkan pengertian di atas, kepuasan kerja merupakan sejauh mana merasa positif atau negatif tentang berbagai aspek dari pekerjaanya. Kepuasan karyawan secara keseluruhan tergantung pada bagaimana perasaan mereka tentang beberapa komponen, seperti pekerjaanya itu sendiri, gaji, promosi, rekan kerja dan pengawasan.

Faktor kepuasan kerja yang secara langsung berkaitan dengan pekerjaan oleh Herzberg disebut motivator factors, yang menunjukkan sesuatu yang menjadi kepuasan karyawan atas pekerjaannya. Sedangkan faktor kepuasan kerja yang berada di lingkungan kerja karyawan yang bersangkutan disebut hygiene factors. Motivator factors (pemotivasian atau intrinsik) itu meliputi: prestasi (achievement), penghargaan (recognition), tanggung jawab (responsibility), promosi (advancement), kemungkinan perkembangan (the possibility of growth), dan pekerjaan itu sendiri (the work itself). Adapun hygiene facfors (faktor pemeliharaan atau ekstrinsik) meliputi: gaji (salary), teknik dan kualitas supervisi (technical and qualify supervision), administrasi dan kebijaksanaan perusahaan (company policies and administration), kualitas hubungan interpersonal 
di antara rekan sekerja; dengan atasan; dan dengan bawahan (quality interpersonal relations among peer; with superiors; and subordinat), keamanan kerja (job security), status, tunjangan tambahan (fringe benefits), dan kondisi kerja (working conditions).

Berdasarkan definisi konsep yang telah diuraikan maka dapat disintesiskan bahwa kepuasan kerja adalah respon perasaan seseorang yang ditunjukkan dalam bentuk sikap positif dan negatif terhadap pekerjaan dan pengalaman kerjanya dalam sebuah organisasi dengan indikator: I) penghargaan yang diterima, 2) pengawasan atasan, 3) hubungan dengan rekan kerja, 4) pekerjaan itu sendiri, 5) kondisi di tempat kerja.

\section{Budaya Organisasi}

Menurut Robert G. Owen budaya orgnisasi dapat dipandang sebagai:

The norm that inform what is acceptable and what is not, the dominant value that the organizational cherises above others, the basic assumption and belief that are shared by member of the organization, the rules of the game that must be observed if one is to get along and be accepted as a member, the philosopy that guide the organization in dealing with its employees and it clients.

Berdasarkan kutipan tersebut dapat dijelaskan bahwa budaya merupakan norma yang menjadi acuan tentang apa yang bisa diterima dan apa yang tidak, nilai-nilai dominan yang dijadikan acuan, asumsi dasar dan keyakinan yang dianut oleh anggota organisasi, aturan yang harus dipelajari oleh anggota baru ketika diterima di organisasi, dan menjadi filosofi yakni acuan dalam menangani masalah-masalah baik di dalam maupun luar organisasi.Kreitner dan Kinicki menyatakan bahwa:

The system of shared norms, beliefs and assumptions which binds people together thereby creating and habits meaning. This system is manifested by customs and habits that exemplify the values and beliefs of the organization.

Penjelasan ini menunjukkan bahwa budaya organisasi adalah sistem norma, keyakinan, dan asumsi makna bersama. Sistem ini diwujudkan dengan adat istiadat dan kebiasaan yang memberikan contoh nilai-nilai dan kepercayaan organisasi.

Pendapat lain dikemukakan West-Burham, "the product of the shared values, beliefs, priorities, expectations and norms that serve to inform that way in which an organisation manifests it self to the world". Budaya merupakan produk yang berhubungan dengan nilai-nilai, keyakinan, prioritas, harapan, dan norma-norma yang berhubungan dengan pelayanan pada sebuah organisasi dan mewujudkannya dalam masyarakat. Mencermati definisi tersebut, budaya terbentuk dari kombinasi antara nilai, keyakinan, norma, dan harapan yang digunakan sebagai suatu ketentuan tidak tertulis yang ditaati dan dianut oleh suatu kelompok tertentu. Pelanggaran terhadap nilai, keyakinan, dan norma tersebut dapat menimbulkan suatu konsekuensi tertentu. Robbins berpandangan bahwa budaya merupakan pola standar prilaku yang dapat diterima dalam suatu kelompok masyarakat. Tokoh ini juga mengemukakan bahwa budaya merupakan suatu sistem yang disepakati bersama. Oleh sebab itu, budaya dapat memadukan individu-individu yang memiliki latar belakang dan kedudukan atau status yang berbeda dalam suatu kelompok masyarakat.

Berdasarkan deskripsi konsep di atas maka dapat disentisiskan bahwa budaya organisasi adalah kesamaan terhadap nilai, norma, dan keyakinan yang ada dalam organiasi yang terbentuk dari proses interaksi antar anggota organisasi untuk mencapai tujuan bersama dengan indikator: I) semangat kebersamaan, 2) keterpaduan dengan sesama anggota organisasi, 3) keyakinan terhadap konsesus nilai, dan 4) kesungguhan terhadap pencapaian tujuan bersama.

\section{Stres Kerja}


Stres dapat dikatakan sebagai akibat dari konflik yang disebabkan karena adanya tekanan, ketegangan, dan tuntutan yang beriringan dengan pekerjaan atau aktivitas hidup manusia yang dapat membuat individu tersebut merasa terbebani dan keberatan untuk menyelesaikan sebagai kewajibannya.

Pendapat W. Slocum tentang stres kerja dinyatakan bahwa:

Job stress is a common and costly problem in the workplace, leaving a few workers untouched. Stres is excitement, feeling of anxiety, and/or physical tension that occurs when the demands placed on an individual are though to exceed the person's ability to cope.

Pendapat lain mengenai stres kerja didefinisikan Richmond (1999:39): work stres is defined as the harmful physical and emotional responses that occur when job requirements do not match the workser's capabilities, resources, and needs. Stres kerja didefinisikan sebagai tanggapan fisikal dan emosional yang membahayakan yang terjadi saat kebutuhan pekerjaan tidak sesuai dengan kapabilitas pekerja, sumber daya dan kebutuhan. Selanjutnya, John Bernardin mengatakan:

Job stress has been defined as a situation where in job related factors interact with a worker to change his or her psychological andlor her psychological condition such that the person is forced to deviate from norma functioning. Stres is consisered to be major problem for workers in today turbulent and highly competitive environment, with its emphasis on cost control, reduced labor expense and higher productivity.

Stres kerja merupakan situasi dimana faktor terkait pekerjaan berinteraksi dengan seorang pekerja untuk mengubah kondisi psikologis sehingga orang tersebut terpaksa menyimpang dari norma yang ada. Stres dikhawatirkan menjadi masalah utama bagi pekerja di lingkungan yang penuh gejolak dan sangat kompetitif saat ini, dengan adanya penekanan pada pengendalian biaya, pengurangan biaya tenaga kerja dan produktivitas yang lebih tinggi

Verna Blewett, Andrea Shaw (2006: 4): Job stress is a widespread concern across all employment sectors and occupational levels, and is commonly reported cause of occupational illness and associatiated organizational outcome. Stres kerja adalah kekhawatiran yang besar di semua sektor pekerjaan dan tingkat pekerjaan, dan umumnya ditunjukkan dari beban kerja yang berat sehingga timbul penyakit sebagai akibatnya tujuan organisasi tidak tercapai

Hans Selye (dalam Riggio, 2003) mendefinisikan stres sebagai sebuah reaksi psikologis untuk menyatakan ancaman dari situasi lingkungan. Dalam perspektif Selye, stres kerja umumnya merujuk pada stres yang disebabkan karena pengaruh lingkungan kerja. Stres kerja bergantung pada cara pandang pekerja, dimana stres merupakan hasil dari persepsi pekerja dalam menyatakan situasi lingkungan sebagai ancaman atau tantangan. Faktor-faktor penyebab stres kerja antara lain intrinsik, peran dalam organisasi, pengembangan karir, hubungan dalam pekerjaan dan individu.

Indikator dari stres kerja menurut Robbins yaitu (I) tuntutan tugas, merupakan faktor yang dikaitkan pada pekerjaan seseorang seperti kondisi kerja, tata kerja letak fisik, (2) tuntutan peran, berhubungan dengan tekanan yang diberikan pada seseorang sebagai suatu fungsi dari peran tertentu yang dimainkan dalam suatu organisasi, (3) tuntutan antar pribadi, merupakan tekanan yang diciptakan oleh pegawai lain, (4) struktur organisasi, gambaran instansi yang diwarnai dengan struktur organisasi yang tidak jelas, kurangnya kejelasan mengenai jabatan, peran, wewenang, dan tanggung jawab, (5) kepemimpinan organisasi memberikan gaya manajemen pada organisasi. Beberapa pihak didalamnya dapat membuat iklim organisasi yang melibatkan ketegangan, ketakutan dan kecemasan.

Dari uraian di atas dapa disintesiskan bahwa stres kerja adalah suatu kondisi ketegangan yang dirasakan seseorang dalam bekerja yang menimbulkan respon adaptif terhadap psikologis dan fisik dengan indicator : adanya tekanan di tempat kerja, tuntutan pekerjaan yang tidak sesuai dengan kemampuan, respon fisiologis dan respon prilaku individu. 


\section{METODE PENELITIAN}

Metode penelitian yang digunakan adalah metode survey dengan pendekatan kuantitatif, metode yang biasa disebut analisis jalur (path analysis) ini bertujuan untuk menjelaskan hubungan atau korelasional kausal beberapa variabel, adapun variabel yang dimaksud adalah pengaruh (I) budaya organisasi terhadap kepuasan kerja, (2) stres kerja terhadap kepuasan kerja, dan (3) budaya organisasi terhadap stres kerja. Untuk melihat pengaruh antara variabel dirancang model hipotetik sebagai berikut:

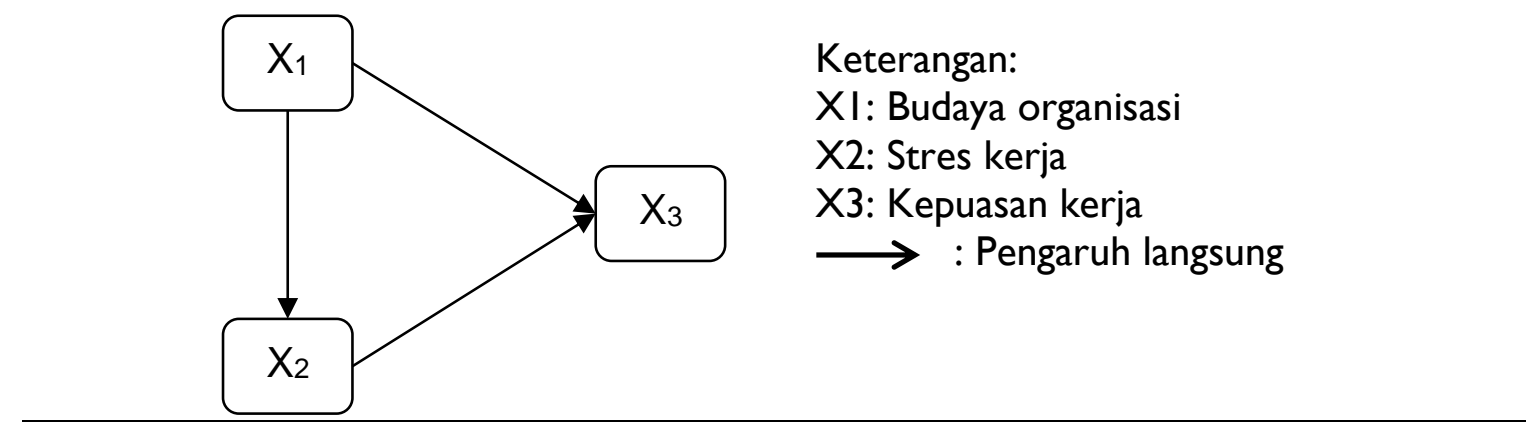

\section{Gambar I: Desain Penelitian}

Penelitian dilakukan pada semua Sekolah Swasta SMA Katolik Se Jakarta Timur, dengan populasi terjangkau pada penelitian ini adalah Guru yang berstatus tetap berjumlah 230 Guru. besar populasi yang harus diambil maka dalam penelitian ini menggunakan sampel 103 Guru SMA, adapun besaran sampel ini diambil dengan mengikuti perhitungan rumusan Slovin. Metode survey yang dilakukan adalah dengan menyebar kuesioner yang didisain menurut variabel yang dipilih, dimana tiap-tiap variabel terdiri dari 5 indikator dengan respon jawaban dalam bentuk skala I sampai 5 .

Sebelum kuesioner ini disebarkan maka diadakan uji coba untuk menentukan validitas dan reabilitas dari masing-masing instrumen. Adapun besaran sampel yang dilibatkan dalam uji coba ini adalah 24 Guru SMA. Analisa dari data hasil uji coba ditujukan untuk menetapkan instrument yang valid dari hasil korelasi product moment antara skor butir dengan skor total, serta perhitungan reliabilitas terhadap konsistensi data angket dengan menggunakan rumus Alpha Cronbach.

\section{HASIL DAN PEMBAHASAN}

\section{Pengaruh Budaya Organisasi Terhadap Kepuasan Kerja.}

Dari hasil perhitungan analisis jalur, pengaruh langsung positif budaya organisasi terhadap kepuasan kerja, nilai koefisien jalur sebesar 0,642 dan nilai $t_{\text {hitung }}$ 6,760 sebesar Nilai $t_{\text {tabel }}$ untuk $\alpha=0,0$ I sebesar2,63 Oleh karena nilai $t_{\text {hitung }}$ lebih besar dari pada nilai $t_{\text {tabel }}$ maka $\mathrm{H}_{0}$ ditolak dan $\mathrm{H}_{1}$ diterima, dengan demikian terdapat pengaruh signifikan antara budaya organisasi dan kepuasan kerja. Budaya organisasi berpengaruh secara langsung positif terhadap kepuasan kerja dapat diterima.

Hasil analisis hipotesis pertama memberikan temuan bahwa budaya organisasi berpengaruh secara langsung positip terhadap kepuasan kerja. Dengan demikian dapat disimpulkan bahwa kepuasan kerja dipengaruhi secara langsung positif oleh budaya organisasi. Semakin tingginya budaya organisasi, semakin tinggi pula kepuasan kerja.

Tabel I. Koefisien Jalur Pengaruh $X_{1}$ terhadap $X_{3}$ 


\begin{tabular}{|c|c|c|c|c|c|c|}
\hline \multirow{2}{*}{ No. } & \multirow{2}{*}{$\begin{array}{l}\text { Pengaruh } \\
\text { Langsung }\end{array}$} & \multirow{2}{*}{$\begin{array}{l}\text { Koefisien } \\
\text { Jalur }\end{array}$} & \multirow{2}{*}{ dk } & \multirow{2}{*}{$t_{\text {hitung }}$} & \multicolumn{2}{|c|}{$t_{\text {tabel }}$} \\
\hline & & & & & $\alpha=0,05$ & $\alpha=0,01$ \\
\hline I. & $\mathrm{X}_{1}$ terhadap $\mathrm{X}_{3}$ & 0,478 & 100 & $6,760 * *$ & 1,98 & 2,63 \\
\hline
\end{tabular}

** Koefisien jalur sangat signifikan $(6,760>2,63$ pada $\alpha=0,0 \mathrm{I})$

Dari hasil pengujian hipotesis pertama dapat disimpulkan bahwa terdapat pengaruh langsung positif budaya organisasi terhadap kepuasan kerja dengan nilai koefisien korelasi sebesar 0,478 dan nilai koefisien jalur sebesar 0,642. Ini memberikan makna budaya organisasi berpengaruh langsung positif terhadap kepuasan kerja.

Hasil penelitian ini senada dengan pandangan dari beberapa ahli diantaranya menurut Scheremerhorn (2012:9), "organizational culture tha shared beliefs and values that influence the behavior of organizational members". Satu hal yang secara kontekstual besar pengaruhnya terhadap perilaku organisasi adalah budaya organisasi, keyakinan dan nilai-nilai yang memengaruhi perilaku dari setiap Guru di dalam organisasi sekolah.

Menurut Colquitt, LePine \& Wesson (2013:535): "Organizational culture as the shared social knowledge within an organization regarding the riles, norms and values that shape the attitudes and behaviors of its employees". Budaya organisasi adalah suatu bentuk pengetahuan sosial dalam suatu organisasi dengan memandang peraturan-peraturan, norma dan nilai-nilai yang membentuk kecakapan dan perilaku setiap anggotanya.

Indikator keberhasilan sekolah dilihat dari output dari sekolah yang menghasilkan para peserta didik yang berkarakter unggul dan berprestasi tinggi. Adapun usaha untuk mewujudkan keberhasilan tersebut diperlukan Guru yang produktivitas kerjanya yang tinggi. Hasil penelitian Stephen P. Robbins (20I5:52I) berpendapat, "this overall perception becomes, in effect, the organization's culture or personality and affects employee performance and satisfaction, with stronger cultures having grater impact."

Guru membentuk persepsi subjektif terhadap organisasi berdasarkan pada faktorfaktor persepsi keseluruhan yang menjadi dasarnya adalah budaya organisasi atau kepribadian yang dapat memengaruhi kinerja dan kepuasan kerja Guru. Dengan budaya yang kuat memiliki dampak yang lebih besar.

Menurut Rae Andrea (2008:128) ada pengaruh antara budaya organisasi dengan kepuasan kerja. "Job satisfaction is a collection of attitudes about the various parts of job. It can be measured simply by asking a person, overall, how satisfied are you with your job?"

Kepuasan kerja merupakan sekumpulan sikap dari beberapa bagian suatu pekerjaan. $\mathrm{Hal}$ ini dapat diuraikan secara sederhana dengan bertanya pada Guru, secara keseluruhan bagaimana tingkat kepuasan anda.

Sedangkan menurut James L. Gibson (2012:104), "job satisfaction is an attitude that individuals have about their jobs. It results form their perception of their jobs, based on factors on the work environment work group affiation, working conditions and fringe benefit". Kepuasan kerja adalah sikap seseorang tentang pekerjaannya yang didasari oleh faktor lingkungan kerja, keamanan kerja, kondisi kerja dan pendapatannya.

Pendapat yang hamper serupa dikatakan oleh E.A.Locke dalam bukunya Steven L.Mc Shane and Mary Ann Von Glinov (2010:108) mengatakan bahwa, "job satisfaction a person evaluation of his/her job and work context, is probably the most studied attitude in organizational behavior". Kepuasan kerja seseorang adalah evaluasi diri dari pekerjaannya dan konteks kerja, mungkin sikap yang paling banyak dirasakan dalam budaya organisasi. 
Seorang Guru yang memiliki kepuasan kerjanya tinggi tentu akan berusaha untuk memberi pelayanan yang maksimal dan lebih professional sehingga tercipta proses pembelajaran yang bermutu. Demikian halnya dengan budaya sekolah yang menjadi kekuatan organisasi untuk mencapai tujuan. Bahkan, ketika kepuasan kerja tidak tercapai maka pimpinan memperkuat nilai-nilai yang terdapat pada budaya sekolah, salah satunya semangat kebersamaan sebagai penyeimbang. Dengan demikian budaya organisasi berpengaruh langsung positif terhadap kepuasan kerja.

\section{Pengaruh Stres Kerja Terhadap Kepuasan Kerja}

Dari hasil perhitungan analisis jalur, pengaruh langsung stres kerja terhadap kepuasan kerja, nilai koefisien jalur sebesar $-0,432$ dan nilai $-t_{\text {hitung }}$ sebesar $-0,6104$ Nilai $t_{\text {tabel }}$ untuk $\alpha=0,0$ I sebesar 2,63 . Oleh karena nilai $t_{\text {hitung }}$ lebih kecil dari pada nilai $t_{\text {tabel }}$ maka $\mathrm{H}_{0}$ ditolak dan $\mathrm{H}_{1}$ diterima, dengan demikian stress kerja berpengaruh secara langsung negative terhadap kepuasan kerja dapat diterima.

Hasil analisis hipotesis kedua menghasilkan temuan bahwa stres kerja berpengaruh secara langsung negative terhadap kepuasan kerja. Berdasarkan hasil temuan tersebut dapat disimpulkan bahwa kepuasan kerja dipengaruhi secara langsung negatif oleh stress kerja. Tingginya stres kerja mengakibatkan rendahnya kepuasan kerja.

Tabel 2. Koefisien Jalur Pengaruh $X_{2}$ terhadap $X_{3}$

\begin{tabular}{|c|c|c|c|c|c|}
\hline \multirow{2}{*}{ No. } & \multirow{2}{*}{$\begin{array}{l}\text { Pengaruh } \\
\text { Langsung }\end{array}$} & \multirow{2}{*}{$\begin{array}{c}\text { Koefisien } \\
\text { Jalur }\end{array}$} & \multirow{2}{*}{$\mathbf{t}_{\text {hitung }}$} & \multicolumn{2}{|c|}{$t_{\text {tabel }}$} \\
\hline & & & & $\alpha=0,05$ & $\alpha=0,01$ \\
\hline I. & $\mathrm{X}_{2}$ terhadap $\mathrm{X}_{3}$ & $-0,432$ & $-6,104 * *$ & 1,98 & 2,63 \\
\hline
\end{tabular}

** Koefisien jalur sangat signifikan $(-6,104<2,63$ pada $\alpha=0,01)$

Dari hasil pengujian hipotesis kedua dapat disimpukan bahwa terdapat pengaruh langsung negatif stress kerja terhadap kepuasan kerja dengan nilai koefisien korelasi sebesar 0,614 dan nilai koefisien jalur sebesar $-0,432$. Ini memberikan makna stres kerja berpengaruh langsung negatif

Berkaitan dengan hal itu, Verna Blewett, Andrea Shaw (2006: 4): Job stress is a widespread concern across all employment sectors and occupational levels, and is commonly reported cause of occupational illness and associatiated organizational outcome. Stres kerja adalah kekhawatiran yang besar di semua sektor pekerjaan dan tingkat pekerjaan, dan umumnya ditunjukkan dari beban kerja yang berat sehingga timbul penyakit sebagai akibatnya tujuan organisasi tidak tercapai.

Hasil penelitian tersebut senada dengan Robert Kreitner and Angelo Kinicki mengungkapkan:

Stres can have very negative effects on organizational behavior and an individual health. Stres is

positively related to absenteeism, turnover, coronary heart disease and viral infection. It is hoped

that managers would attempt to reset the negative effects of stres by improving job satisfaction. Stres dapat memiliki dampak yang sangat negatif pada perilaku organisasi dan kesehatan individu. Stres secara positif berhubungan dengan absensi, turnover, penyakit jantung coroner, dan inveksi virus. Jadi, harapan organisasi manajer akan berusaha untuk mengelola efek negatif dari stres dengan meningkatkan kepuasan kerja.

Menurut Anwar (1993), Stres kerja adalah suatu perasaan yang menekan atau rasa tertekan yang dialami karyawan dalam menghadapi pekerjaannya. Stres kerja tidak dapat dihindari, namun stres kerja dapat dikurangi dan dikelola. Stres kerja apabila dikelola dengan baik dapat 
menjadi pendorong dan meningkatkan intensitas kerja, sedangkan apabila tidak dikelola dengan baik stres kerja akan menimbulkan permasalahan yang berdampak negatif bagi individu dan sekolah.

Berdasarkan uraian di atas maka sekolah perlu serius mengatasi permasalahan yang berkaitan dengan stres kerja karena dampaknya merugikan organisasi karena berakitabat pada kepuasan kerja Guru yang menurun. Dengan demikian, stress kerja berpengaruh negatif terhadap kepuasan kerja.

\section{Pengaruh Budaya Oganisasi terhadap Stres Kerja}

Dari hasil perhitungan analisis jalur, pengaruh langsung budaya organisasi terhadap stress kerja, nilai koefisien jalur sebesar $-0,381$ dan nilai $t_{\text {hitung }}$ sebesar $-4,584$. Nilai $t_{\text {tabel }}$ untuk $\alpha=0,0$ I sebesar 2,63 . Oleh karena nilai $t_{\text {hitung }}$ lebih kecil dari pada nilai $t_{\text {tabel }}$ maka $\mathrm{H}_{0}$ ditolak dan $\mathrm{H}_{1}$ diterima, dengan demikian budaya organisasi berpengaruh secara langsung negatif terhadap stress kerja dapat diterima.

Hasil analisis hipotesis ketiga memberikan temuan bahwa budaya organisasi berpengaruh secara langsung negatif terhadap kepuasan kerja. Dengan demikian dapat disimpulkan bahwa stres kerja dipengaruhi secara langsung negatif oleh budaya organisasi. Tingginya stress kerja mengakibatkan rendahnya budaya organisasi.

Tabel 3. Koefisien Jalur Pengaruh $X_{1}$ terhadap $X_{2}$

\begin{tabular}{|c|c|c|c|c|c|}
\hline \multirow{2}{*}{ No. } & $\begin{array}{c}\text { Pengaruh } \\
\text { Langsung }\end{array}$ & $\begin{array}{c}\text { Koefisien } \\
\text { Jalur }\end{array}$ & $\mathbf{t}_{\text {hitung }}$ & \multicolumn{2}{|c|}{$\mathbf{t}_{\text {tabel }}$} \\
\cline { 3 - 6 } & & & $\boldsymbol{\alpha}=\mathbf{0 , 0 5}$ & $\boldsymbol{\alpha}=\mathbf{0 , 0 1}$ \\
\hline I. & $\mathrm{X}_{1}$ terhadap $\mathrm{X}_{2}$ & $-0,38 \mathrm{I}$ & $-4,584 * *$ & $\mathrm{I}, 98$ & 2,63 \\
\hline
\end{tabular}

Dari hasil pengujian hipotesis ketiga dapat disimpulkan bahwa terdapat pengaruh langsung negative budaya organisasi terhadap stres kerja dengan nilai koefisien korelasi sebesar $-0,38 \mathrm{I}$ dan nilai koefisien jalur sebesar $-0,38 \mathrm{I}$. Dengan demikian terbukti pendapat Laurie J. Mullins:

There appears little doubt that one of the major adverse influences on job satisfaction, work performance and productivity, and absenteeism and turnover is the incidence of stres at work. Stres is a complex and dynamic concepts. It is a source.

Kemungkinan besar terlihat bahwa stress adalah salah satu kerugian besar yang berpengaruh terhadap kepuasan kerja, kinerja dan produktivitas serta budaya kerja yang buruk seperti ketidakhadiran dan keluar masuknya karyawan. Ini memberikan makna budaya organisasi berpengaruh langsung negatif terhadap stres kerja kerja.

Suprihanto dkk (2003:63-64) mengatakan bahwa dari sudut pandang organisasi, manajemen mungkin tidak khawatir jika karyawannya mengalami stres yang ringan. Alasannya karena pada tingkat stres tertentu akan memberikan akibat positif, karena hal ini akan mendesak mereka untuk melakukan tugas lebih baik. Tetapi pada tingkat stres yang tinggi atau stres ringan yang berkepanjangan akan membuat budaya organisasi menjadi lemah. Dari uraian di atas terdapat pengaruh negatif stress kerta terhadap budaya organisasi.

Ringkasan model analisis jalur dapat terlihat pada gambar sebagai berikut: 


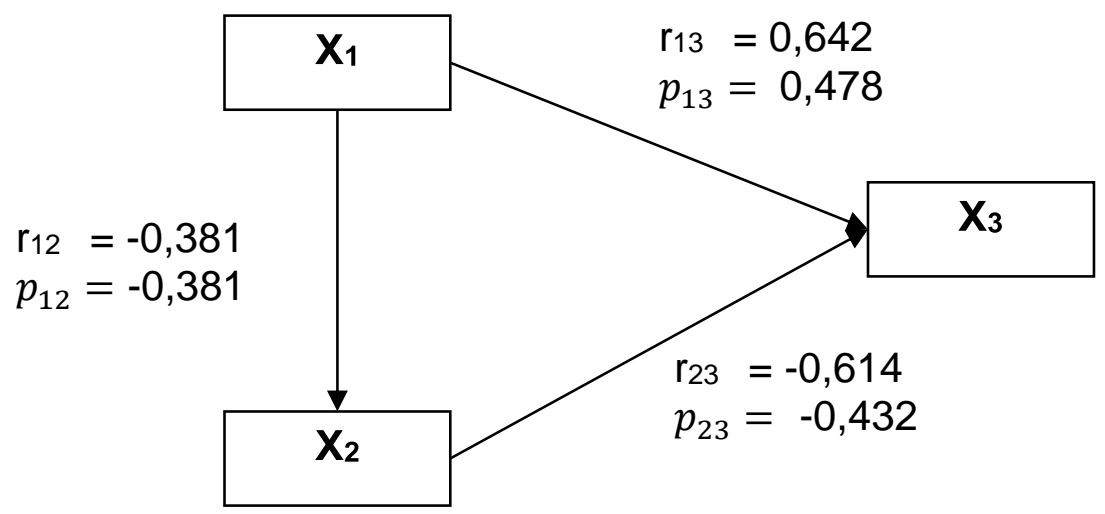

Gambar 2: Model Empiris Antar Variabel

\section{KESIMPULAN}

Berdasarkan hasil penelitian yang dilakukan terhadap Guru-Guru SMA Katolik Se Jakarta Timur maka diperoleh kesimpulan penelitian sebagai berikut:

I. Budaya organisasi berpengaruh langsung positif dan signifikan terhadap kepuasan kerja, artinya, budaya organisasi yang kondusif dapat meningkatkan kepuasan kerja Guru SMA Katolik Se-jakarta Timur.

2. Stres kerja berpengaruh langsung negatif terhadap kepuasan kerja, artinya stres kerja yang tinggi mengakibatkan rendahnya kepuasan kerja Guru SMA Katolik Se-Jakarta Timur.

3. Budaya organisasi berpengaruh langsung negatif terhadap stres kerja. Artinya, budaya sekolah yang kondusif dapat menurunkan stres kerja Guru SMA Katolik Se-Jakarta Timur.

Melihat hasil penelitian adanya pengaruh budaya organisasi dan stres kerja terhadap kepuasan kerja para Guru SMA di Sekolah Swasta Katolik se-Jakarta Timur. Maka guna meningkatkan kepuasan kerja para Guru SMA Pihak sekolah harus berkomitmen menjalankan budaya organisasinya dan mengelola tingkat stres kerja para Guru. Maka implikasi dari hasil penelitian ini diarahkan pada upaya meningkatkan kepuasan kerja para Guru melalui peningkatan budaya organisasi dan menurunkan tingkat stres kerja.

Adapun saran yang dapat diberikan kiranya Kepala Sekolah menjadi teladan di dalam menjalankan nilai-nilai budaya organisasi yang ada, Yayasan Sekolah membantu pimpinan sekolah dalam hal memberikan masukan dan pengarahan untuk peningkatan nilai-nilai budaya organisasi yang berlandaskan ajaran katolik, serta membantu pimpinan sekolah dalam hal kebijakan pengupahan, penghargaan dan promosi jabatan yang layak bagi para Guru. Serta para Guru Secara sungguh menjalankan nilai-nilai budaya organisasi yang ada, disiplin dalam bekerja, menghormati pimpinan sekolah dan sesama rekan kerja, sehingga tercipta suasana saling dukung sehingga tingkat kepuasan kerja dapat terpenuhi.

\section{DAFTAR PUSTAKA}

Angelo Kinicki, Brian K. Williams, Management a Practical Introduction $5^{\text {th }}$ Ed. (New York: Mc Graw Hill, 20I I).

Bernardin, H John. Human resources Management: An Experiental Approach. New York: MC Graw Hill International, 2007.

Burnham, John West, Managing Quality in School Effective Strategies for. Quality-Based School Improvement. London: Prentice Hall, 1997.

Colquitt, Jason A., Jeffery A. Le pine, Michael J. Wesson, Organizational Behaviour Improving Performance and Commitment in the Workplace $4^{\text {th }}$ Edition. New York: McGraw Hill, 2015. 
Cotton, J., And J. Tuttle, (1986), Employee Turnover: A Meta Analysis And Review With Implications For Research. Academy Of Management Review. II (I), p. 55-70. ( https://www.researchgate.net/profile/John_Cotton3/publication )

Edgar Schein di dalam Ivancevich, Konopaste and Matteson, Organizational Behaviour and Managament. New York : McGraw Hill, 2008.

George, Jennifer M. Gareth R. Jones, Understanding and Managing Organizational Behaviour $6^{\text {th }}$ Edition. United States of America: Pearson, 2012

Griffin Moorhead, Organizational Behavior. New York: Houghton Muffin Company, 2007.

Hellriegel, D and Slocum, J. W, Organizational Behavior. Mason: South Western, Cengage Learning, 20II.

Hellriegel, Don, John W. Slocum Jr., Organizational Behavior, New Jersey: Prentice Hall. Englewood Cliffts, 1988.

John R. Schermerhorn, James G. Hut And Richard N. Osborn, Organizational Behavior, Tenth Edition. New York: John Wiley \& Son, Inc, 2007.

John Shield, Managing Employee Performance and Reward Concept, Practice, Strategies. New York: Cambridge University. Press, 2007.

Jujun S., Suriasumantri, Filsafat Ilmu: Sebuah Pengantar Populer. Jakarta: Pustaka Sinar Harapan, 2003.

Kusman, Maman, Perilaku Organisasi. Bandung: Magister Manajemen Universitas Padjajaran, 1999.

Leslie W., Rue and Lloyd L., Byars, Supervision Tenth Edition. New York: McGraw-Hill Companies, 2010.

Luthans, Fred, Organizational Behavior II th edition. New York: Mc Graw Hill, Inc., 2005.

Ndraha T., Budaya Organisasi. Jakarta: PT. Rineka Cipta, 2003.

Purwana Dedi, dkk., Pengantar Ilmu Organisasi. Bogor: In Media, 2017.

Robbins, Stephen P. and Timothy A. Judge, Organizational Behavior $15^{\text {th }}$ Edition. New Jersey: Pearson International Education, 2013.

Robert G. Owen, Organizational Behavior in Education. Boston: Allyn and Bacon, I99I.

Robert Kreitner and Angelo Kinicki, Organizational Behaviour. New York: McGraw Hill Education, 2007.

Robert Kreitner, and Angelo Kinicki, Organizational Behaviour 9 Edition. New York: McGraw Hill, $201 \mathrm{I}$.

Schein, Edgar H., Organizational Culture and Leadership $3^{\text {rd }}$ Edition. San Francisco: Jossey-Bass, 2004.

Spector, Paul, Job Satisfaction, Application, Assessment, Cause and Consequences. New Delhi: Sage Publication Inc., 1997.

Tika, Pabundu, Budaya Organisasi dan Peningkatan Kinerja Perusahaan. Jakarta: PT. Bumi Aksara, 2006. 